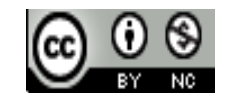

Journal of Education, Teaching, and Learning is licensed under

A Creative Commons Attribution-NonCommercial 4.0 International License.

\title{
Pro-Social Behaviour ANALysis of StUdents THROUgh STUDENTS' ORGANIZATIONS
}

\author{
Yayuk Hidayah $^{1)}$, Yusuf Faisal $\mathrm{Ali}^{2)}$, Anis Suryaningsih ${ }^{3)}$ \\ ${ }^{1)}$ Universitas Ahmad Dahlan, Yogyakarta, Indonesia \\ E-mail: yayuk.hidayah@pgsd.uad.ac.id \\ ${ }^{2)}$ STKIP Pasundan, Cimahi, Indonesia \\ E-mail: yusuffaisalali2016@gmail.com \\ ${ }^{3)}$ Universitas Sebelas Maret, Surakarta, Indonesia \\ E-mail: anissuryaningsih@staff.uns.ac.id
}

\begin{abstract}
Student organization as a place to develop the talents of the students in the form of aspirations, ideas, and creativity to provide opportunities for students to be able to nurture their sense of organization. In student organizations, students are met with certain conditions that bring on pro-social attitudes. The purpose of this study is to analyze, describe, and assess the pro-social behaviour of students through student organizations. This research is descriptive qualitative research. Collecting data through observation, interviews and documentation. Analysis of the data is done by using the model of Miles and Huberman. This study results that students involved in student organizations have social behaviours such as empathy, social responsibility, and low egocentrism. The factors that affect student Pro-social attitudes are the environment, knowledge and personality. Mankind as the main source in the organization should be able to develop individuals with certain criteria. Coaching intensively and encouragement over the ownership of Pro-social attitudes for students are solutions to the emergence of the smart and good citizen.
\end{abstract}

Keywords: Pro-Social; Student Organization; Student Behaviour

\section{INTRODUCTION}

Unity is the foundation since the first of the Indonesian nation. The realm of unity is often described as an embodiment of the adage "United we stand, divided we fall". This maxim requires togetherness and keep splits hemisphere. In the Indonesian context, togetherness manifests itself in mutual aid activities. Cooperation itself in its development gradually becomes strange, because of the emergence of individualism as the attitude of the negative effects of globalization. The decrease of mutual assistance in the community should be anticipated to continue to nourish the commitment of togetherness and care for others. Indonesian youth are appropriately introduced to the attitude of socialization, mutual help and so forth to anticipate the decrease of cooperation.

In connection with globalization, in this article, the researchers are interested to describe the pro-social behaviour of students involved in student organizations. Pro- social behaviour analysis researches students dug to address a series of moral problems of globalization (Himes, 2008), Pro-social behaviour is attached to behaviours that are owned by a volunteer in the form of action to help others without expecting benefit from the rescue actions. The existence of students in student organizations with some organization activities can provide organizational knowledge as well as to examine personality through interaction within the organization.

Related to pro-social, some academics have attempted to explain the true side of pro-social. Haimanti (2019) argues that pro-social reinforces the role as an important source of social support in enhancing synergistic relations with proenvironment attitudes. Besides, Manesi, Van Doesum, and Lange (2017) argued that pro-social behaviour includes various actions intended to benefit others. It is not limited to cooperation, sharing, helping, charity, and volunteering.

Martela and Ryan (2016) argued that some studies have shown that pro-social behaviour is associated with increased 
welfare. Pro-social is a consideration of attitudes that reflects moral principles. It is following the opinion of Malti, Dys, and Zuffianò (2016) that moral development illustrates the emergence and change in understanding, individual feelings, and moral principles throughout life. Besides, Kaur (2019) added if social behaviour can be described as combining sympathy and concern for others and acting in an approach to help or benefit a variety of people.

Indeed, pro-social behaviour aims to build positive, empathic, cooperative and socially responsible relationships to benefit others. Pro-social behaviour has positive qualities that are beneficial to oneself and society. Pro-social behaviour becomes an expression of a positive attitude that can build a good social relation. In this case, Kenny, Haugh, and Fotaki (2019) assumed that the attachment to pro-social work emerged as an integral part of the creation of social enterprises.

On the other hand, pro-social behaviour represents a broad category of actions determined by several significant segments of society and a social group to be generally beneficial to others (Penner et al., 2005). Additionally, Morrison (2006) argued that the possibility of violating prosocial rules is positively related to job autonomy, behaviour, and risk-taking tendencies.

Klein holds that to find out the meaning in life is a basic need for everyone while motivating pro-social behaviour is a fundamental social need. Silva et al. (2019) stated that different motivational motivation and processing of social reward stimulus can result from behavioural responses that are different from typical development when involved in the social world.

Some studies on the History of Pro-social behaviour and organization among others can be seen further. The results of research on analyzing social behaviour in fifth-grade students of elementary school have found that they are helpful, generous, open-minded, act honestly, and cooperative (Kuswendi, 2018). Baker (2008) analyzes the differences in the academic success of students involved in extracurricular activities during college by involving six types of student organizations on college African-Americans and Latinos with 27 different students has found that student organizations differently affected academic performance, depending on the type of organization, race and the sex of the student. The relationship between social class and Prosocial behaviour has been defined broadly as an act intended to help others, can vary as a function of contextual factors.

Three studies examined how to make Pro-social actions public versus personal generate a result that a unique strategy for dealing with others develops based on one's position in the class hierarchy (Kraus \& Callaghan, 2016). Research with 482 respondents in the community of Baton Rouge are testing the hypothesis that different types of Prosocial behaviour are motivated by a variety of ways to meet the need for dealing with life outside and has revealed five factors of Pro-social (activism for peace, donation, donor proximal, family communication, and security of the family), and two social factors (the search for pleasure are not as expected, and illegal behaviour) (Mathews \& Kling, 1988).
Procházka \& Vaculík (2011) which focused on the relationship between Pro-social behaviour and the expectation of Pro-social behaviour from others produce the connection between Pro-social behaviour and expectations are significantly manifested by the expectation of Pro-social behaviour towards other people in real situations. The people, who behave more Pro-social, express more clear to others that they should help others.

Based on the description of previous research found that Pro-social behaviour can grow along with the process of adaptation and socio-emotional of individuals. Meanwhile, the involvement in student organizations is helpful for students as a place to train social behaviour, because, in the organization, students are met with a lot of people, so they can train their social intelligence.

Based on the background issue, the researchers are interested to study more about the Pro-social behaviour of students through student organizations. The problem of this research is "How Pro-social behaviour of students through student organizations?" The practical benefit of the research is as contribute ideas to improve the Pro-social behaviour of students.

\section{Methodology}

This study used a qualitative descriptive. The selection was based on descriptive qualitative research focused that capture the phenomenon of Pro-social students in students' organization. Qualitative research is research that produced words based on the observed behaviour (Moleong, 2002). The phenomenon of Pro-social behaviour of students in students' organization would be heavily influenced by many factors, thus outlining the phenomenon of qualitative methods of Pro-social students in students' organization as a whole.

The object of this research was based on qualitative research arguments on the object in the form of places, actors, and activities (Sugiyono, 2009). The subjects were 24 students from different departments involved in student organizations or Student Executive Body (BEM) in eight (8) different campuses in Yogyakarta Indonesia that were University of Gadjah Mada, Yogyakarta State University, University of Sanata Dharma, State Islamic University of Sunan Kalijaga Yogyakarta, University of Atma Jaya, Ahmad Dahlan University, Indonesian Islamic University, and Duta Wacana Christian University. The distribution of research subjects can be seen in Table I.

The collection of data was done through observation, interviews and documentation. Analysis of the data was done by using the model of Miles and Huberman's data reduction, data display, and concluding. Miles and Huberman asserted that data analysis occurred simultaneously (Silalahi, 2009). 
TABLE I

DISTRIBUTION OF STUDY SUBJECTS

\begin{tabular}{lll}
\hline Demographic & Number & Total \\
\hline Gender & & \\
Male & 15 & 15 \\
Female & 10 & 9 \\
& & \\
Age (in Years) & $18-20$ & 16 \\
& $21-24$ & 8
\end{tabular}

Education level Currently Studying to Become a bachelor

\begin{tabular}{|c|c|c|}
\hline \multirow[t]{27}{*}{ Department } & Management & 3 \\
\hline & Psychology & 1 \\
\hline & English & 2 \\
\hline & Language & \\
\hline & Education & \\
\hline & Islamic & 1 \\
\hline & Education & \\
\hline & Chemical & 1 \\
\hline & Engineering & \\
\hline & Biology & 2 \\
\hline & Architecture & 1 \\
\hline & Education & 2 \\
\hline & Guidance and & \\
\hline & Counseling & \\
\hline & Dance & 1 \\
\hline & Education & \\
\hline & Biology & 3 \\
\hline & Economic & 3 \\
\hline & Education & \\
\hline & Communicatio & 2 \\
\hline & $\begin{array}{l}\mathrm{n} \\
\text { Public }\end{array}$ & 1 \\
\hline & $\begin{array}{l}\text { Administratio } \\
\mathrm{n}\end{array}$ & \\
\hline & Engineering & 1 \\
\hline & Industry & \\
\hline & The Total of & 24 \\
\hline & The & \\
\hline & Participant & \\
\hline
\end{tabular}

Source: Research Data, 2019

\section{RESULTS AND DISCUSSION}

In this section, the researchers tried to explain the findings of the research following relevant theory. Based on the formulation of the problem, the results and discussion of this research are combining directly between the findings of the field with the relevant theory. The analysis of Pro-social behaviour of students through student organizations is distinguished, then the researchers interpret according to the meaning resulted in findings. Pro-social behaviour of students through student organizations are obtained based on data from interviews, observation and documentation of the study sites.

Based on data obtained from the study, the results of the study are students involved in student organizations have social behaviours such as empathy, social responsibility and low egocentrism. In this case, Bierhoff (2015) stated that pro-social behaviour can range from small favours to large acts. It might only take a moment, or it might be a long-term effort. This can be done without conscious thought or weighing pros and cons. On the other hand, Bailey and Cooker (2018) stated that pro-social behaviour is effectively encouraged by educational environment programs that are implemented in a variety of contexts.

Following the research finding, the students involved in the student's organization have harmonious social behaviour. It means that the involvement in student's organization has an impact on their lives. Caspersz and Olaru (2013) clarified that pro-social activities are intended to benefit someone or something. Then, Briggs, Peterson, and Gregory (2009) explained that other-oriented values and reasons seem far more influential than voluntary self-focused values and reasons.

In preparing for good citizenship, the fundamental experience in the form of community service is still important for citizens, though it still requires further study (Horn, 2012). Loyalty, visionary, capability are examples of the attitudes of volunteers. However, when juxtaposed with the Pro-social behaviour of students through student organizations becomes instrumental in introspection whether attitudes and behaviours are rooted in self-students.

The presence of students in the student's organization can be a vehicle in developing student's pro-social behaviour. This is consistent with Smith's statement (2015) that the broad environment provides a more valid understanding of the kind of culture favoured in pro-social actions. Then, Curtin, Stewart, and Cole (2015) stated that in intersectional theory, pro-social action is increasingly seen as a valuable tool for understanding and contextualizing the complexity of an individual's life. However, psychologists generally focus on the Intersection. Thus, social behaviour becomes individual differences that influence social attitude and behaviour.

The existence of student organizations, especially students in the Student Executive Board (BEM) has indirectly become the arena in training, honing and fostering Pro-social attitudes consciously and unconsciously in students' personality. In an organization, pride and gratitude are measured as the tendencies disposition of a leader (Michie, 2009), Pro-social behaviour is a sense of concern for others so that the growing sense of sincerity without expecting anything in return. Meanwhile, being useful to others is Prosocial behaviour (Toumbourou, 2016).

A contribution physically and physically is performed to lighten the burden of others. Tests on the relationship between individuals, groups and Pro-social behaviour towards members of the team that transactions are carried out on 123 students who are in the 45 teams has produced that the individual is more likely to behave Pro-social 
against members of the group when they feel good. The relevance of confidence the team has a more powerful influence on behaviour than Pro-social team (Cuadrado \& Tabernero, 2015)

If observed, the results of the study show that the existence of a student's organization can be an exercise or habit for students to be accustomed to social behaviour. Leventhal et al. (2007) stated that inhabiting is an important component of an adaptive affective processing system that promotes effective responses to prominent stimulus and prevents compulsive behaviour. Then, Bolhuis, Kolling, and Knopf (2015) explained that individual differences with other individuals are important social cues that can help determine the next attitude for the individual.

The era of globalization recalls the existence of local wisdom as a way of maintaining the existence of local wisdom in preserving pro-social action and behaviour (Hidayah, Feriandi, \& Saputro, 2019). The pro-social of students through student organizations can be widened in the effort to restore the national identity that works together, united which constitutes the values of Pancasila as the state ideology. The transfer process and implementation of Pancasila through student organizations become an extension of the function of education, although it is generally in the field of education and can be said that the success of the learning process can be influenced by the choice of learning approaches (Hidayah, Nufikha, \& Suyitno, 2019). Students as a young generation have a vital role in the life of the nation (Sanusi \& Darmawan, 2016), and it is a proper attitude that can nourish awareness of the social conditions within each of the next generation.

The scope of community life requires interaction with mutual respect and love for one another for the sake of the establishment of harmony in life. The study tested the hypothesis that mortality salience (MS) will increase Prosocial behaviour and it indicates that MS increases charitable donations and increase support for the confederation. However, MS significantly reduces the signing of organ donation and reduce support for the confederation (Hirschberger, Ein-Dor, and Almakias, 2008).

Following the results of research, the Pro-social behaviour of students through student organizations can also be affected by several factors such as personality, environment and knowledge. Engagement consists of "learning behaviour" and pro and anti-social behaviour. Both are associated with academic performance (Finn, Pannozzo, and Achilles, 2003).

There are some pieces of evidence of pro-social behaviour of students through student organizations that require an order to advance and improve the character development of students. In the globalization era, character education can be a solution in creating a character that conformed to the character of the nation (Retnasari, Suyitno, \& Hidayah, 2019). Pro-social behaviour of students through student organizations is a useful and positive action. Pro-social behaviour is an action that has positive results (Amini, 2016). Besides, the pro-social behaviour of students through student organizations has organized some ego, so that it can be beneficial to the environment around students. Their prosocial behaviour is a real form of conceptualization to the understanding of personality traits to consider aspects of globalization (Malihah, 2015)

Pro-social behaviour of students through student's organization has organized various moral decisions. Widodo (2018) argued that humanist education will make the attitude of understanding and that the students will be actualized various human potencies. Then, Suyatno et al. (2019) argued that the value and role of the model in education's value is the most dominant strategy for processing values in students. Therefore, the pro-social behaviour of students that emerge in student's organization can be education's value for students.

Through student organizations, student pro-social behaviour can be honed as urgency abilities in conflict resolution that arise, due to a lot of encouragement (Hidayah, Suyitno, \& Retnasari, 2019). The dynamics of personality gives a sensation that an individual is aware of the specific condition. A study investigates the role of behaviour can affect the attitude of African-American teenagers, among others produce role models of pro-social behaviour that is not directly related to the attitude of teenagers towards violence (Hurd, Zimmerman, \& Reischl, 2010). In the student movement, there found that sometimes the student compatibility tested with a series of disagreements, challenges in adaptation and the environment. This condition is a separate evaluation of the pro-social attitudes of students.

\section{CONCLUSIONS}

Based on the results and discussion, there found that student organization becomes a place to develop Pro-social attitudes of students. Pro-social attitudes of students include empathy, social responsibility and low egocentrism. The factors that affect student Pro-social attitudes are the environment, knowledge and personality. Mankind as the main source in the organization should be able to develop individuals with certain criteria. Coaching intensively and encouragement over the ownership of Pro-social attitudes for students are solutions to the emergence of the smart and good citizen.

\section{REFERENCES}

Amini, Y. (2016). Perilaku Prososial Peserta Didik Sekolah Dasar Berdasarkan Jenis Kelamin dan Implikasinya terhadap Bimbingan dan Konseling: Studi Deskriptif terhadap Peserta Didik Kelas Tinggi di SD Miftahul Iman Tahun Ajaran 2015/2016. Skripsi. Bandung: Universitas Pendidikan Indonesia.

Bailey, L., \& Cooker, L. (2018). Who Cares? Pro-social education within the programmes of the International Baccalaureate. Journal of Research in International Education, 17(3), 228-239. https://doi.org/10.1177/1475240918816405

Baker, C. N. (2008). Under-represented college students and extracurricular involvement: the effects of various 
student organizations on academic performance. Soc Psychol Educ. https://doi.org/10.1007/s11218007-9050-y

Bierhoff, H. W. (2015). Prosocial Behaviour. https://www.blackwellpublishing.com/content/hews tonesocialpsychology/chapters/chapter9.pdf

Bolhuis, J., Kolling, T., \& Knopf, M. (2015). Looking in the eyes to discriminate: Linking infants' habituation speed to looking behaviour using faces. International Journal of Behavioral Development, 40(3), 243-252. https://doi.org/10.1177/0165025414564094

Briggs, E., Peterson, M., \& Gregory, G. (2009). Toward a Better Understanding of Volunteering for Nonprofit Organizations: Explaining Volunteers' Pro-Social Attitudes. Journal of Macromarketing, 30(1), 61-76. https://doi.org/10.1177/0276146709352220

Caspersz, D., \& Olaru, D. (2013). Why do students differ in the value they place on pro-social activities? Journal of Sociology, 51(4), 1017-1038. https://doi.org/10.1177/1440783313492239

Cuadrado, E., \& Tabernero, C. (2015). Affective balance, team prosocial efficacy and team trust: A multilevel analysis of prosocial behavior in small groups. PLoS One, 10(8). https://doi.org/10.1371/journal.pone.0136874

Curtin, N., Stewart, A. J., \& Cole, E. R. (2015). Challenging the Status Quo: The Role of Intersectional Awareness in Activism for Social Change and ProSocial Intergroup Attitudes. Psychology of Women Quarterly, 39(4), 512-529. https://doi.org/10.1177/0361684315580439

Finn, J. D., Pannozzo, G. M., \& Achilles, C. M. (2003). The "Why's" of Class Size: Student Behavior in Small Classes. Review of Educational Research, 73(3), 321-368. https://doi.org/10.3102/00346543073003321

Haimanti, B. (2019). Do pro-social students care more for the environment? International Journal of Sustainability in Higher Education, 20(4), 761-783. https://doi.org/10.1108/IJSHE-11-2018-0223

Hidayah, Yayuk, Nufikha, Ulfah., \& Suyitno, S. (2019). Analisis Pendekatan Pembelajaran Mata Kuliah Wajib Umum Pancasila dan Pendidikan Kewarganegaraan Di Perguruan Tinggi. JPK (Jurnal Pancasila dan Kewarganegaraan), 4(1). https://doi.org/10.24269/jpk.v4.n1.2019.pp22-33

Hidayah, Y., Feriandi, Y. A., \& Saputro, E. A. V. (2019). Transformasi Kearifan Lokal Jawa dalam Pendidikan Karakter Sekolah Dasar. AULADUNA: Jurnal Pendidikan Dasar Islam, 6(1), 50-61.

Hidayah, Y., Suyitno, \& Retnasari, L. (2019). Analisis Kemampuan Resolusi Konflik Siswa Sekolah Dasar. (JKPD) Jurnal Kajian Pendidikan Dasar, 4(1).

Himes, K. R. (2008). Globalization with a Human Face: Catholic Social Teaching and Globalization. Theological Studies, 69(2), 269-289. https://doi.org/10.1177/004056390806900202
Hirschberger, G., Ein-Dor, T., \& Almakias, S. (2008). The Self-Protective Altruist: Terror Management and the Ambivalent Nature of Prosocial Behavior. Personality and Social Psychology Bulletin, 34(5), 666-678. https://doi.org/10.1177/0146167207313933

Horn, A. S. (2012). The cultivation of a prosocial value orientation through community service: An examination of organizational context, social facilitation, and duration. Journal of Youth and Adolescence, $\quad 41(7), \quad 948-68$. https://doi.org/10.1007/s10964-011-9714-y

Hurd, N. M., Zimmerman, M. A., \& Reischl, T. M. (2010) Role Model Behavior and Youth Violence: A Study of Positive and Negative Effects. The Journal of Early Adolescence, 31(2), 323-354. https://doi.org/10.1177/0272431610363160

Kaur, R. (2019). A Review on Prosocial Behavior: Social Psychology. https://doi.org/10.13140/RG.2.2.35397.91360

Kenny, K., Haugh, H., \& Fotaki, M. (2019). Organizational form and pro-social fantasy in social enterprise creation. Human Relations, 73(1), 94-123. https://doi.org/10.1177/0018726718821413

Klein, N. (2016). Prosocial behavior increases perceptions of meaning in life. The Journal of Positive Psychology. https://doi.org/10.1080/17439760.2016.1209541

Kraus, M. W., \& Callaghan, B. (2016). Social Class and Prosocial Behavior: The Moderating Role of Public Versus Private Contexts. Social Psychological and Personality Science, 7(8), 769-777. https://doi.org/10.1177/1948550616659120

Kuswendi, U. (2018). Upaya Guru Dalam Mengembangkan Perilaku Prososial (Prosocial Behavior) Siswa Sekolah Dasar (Studi Kasus Di Kelas V Sd Assalaam Kota Bandung). Thesis. Bandung: Universitas Pendidikan Indonesia.

Leventhal, A. M., Martin, R. L., Seals, R. W., Tapia, E., \& Rehm, L. P. (2007). Investigating the dynamics of affect: Psychological mechanisms of affective habituation to pleasurable stimuli. Motiv Emot, 31, 145-157. https://doi.org/10.1007/s11031-007-90598

Malihah, E. (2015). An ideal Indonesian in an increasingly competitive world: Personal character and values required to realise a projected 2045 'Golden Indonesia.' Citizenship, Social and Economics Education, 14(2), 148-156. https://doi.org/10.1177/2047173415597143

Malti, T., Dys, S. P., \& Zuffianò, A. (2016). The Moral Foundations of Prosocial Behaviour. In Prosocial behaviour (pp. 27). Montreal: Encyclopedia early childhood development.

Manesi, Z., Van Doesum, N., \& Lange, P. (2017). Prosocial Behavior (pp. 1-4). https://doi.org/10.1007/978-3319-28099-8_1894-1

Martela, F., \& Ryan, R. M. (2016). Prosocial behavior increases well-being and vitality even withou 
contact with the beneficiary: Causal and behavioral evidence. Motiv Emot, 40, 351-357.

Mathews, R. C., \& Kling, K. J. (1988). Self-Transcendence, Time Perspective, and Prosocial Behavior. Journal of Voluntary Action Research, 17(2), 4-24. https://doi.org/10.1177/089976408801700202

Michie, S. (2009). Pride and Gratitude: How Positive Emotions Influence the Prosocial Behaviors of Organizational Leaders. Journal of Leadership \& Organizational Studies, 15(4), 393-403. https://doi.org/10.1177/1548051809333338

Moleong, L. (2002). Metodologi Penelitian Kualitatif. Bandung: PT. Remaja Rosdakary.

Morrison, E. W. (2006). Doing the Job Well: An Investigation of Pro-Social Rule Breaking. Journal of Management, 32(1), 5-28. https://doi.org/10.1177/0149206305277790

Penner, L. A., Dovidio, J. F., Piliavin, J. A., \& Schroeder, D. A. (2005). PROSOCIAL BEHAVIOR: Multilevel Perspectives. Annu. Rev. Psychol, 56(14), 1-14. https://doi.org/10.1146/annurev.psych.56.091103.0 70141

Procházka, J., \& Vaculík, M. (2011). The Relationship Between Prosocial Behavior And The Expectation Of Prosocial Behavior. Studia Psychologica, 54(3), 363-372.

Retnasari, L., Suyitno, \& Hidayah, Y. (2019). Penguatan Peran Taman Pendidikan Alquran ( TPQ ) Sebagai Pendidikan Karakter Religius. Jurnal SOLMA, 08(01), 32-38.

Sanusi, A. R., \& Darmawan, C. (2016). Implementasi Pendidikan Politik Dalam Membentuk Karakter Kepemimpinan Lintas Budaya Pada Generasi Muda Demi Mewujudkan Budaya Politik Pancasila (Studi Deskriptif Terhadap Organisasi Kepemudaan Gerakan Pemuda Ansor Jawa Barat). JPIS, Jurnal Pendidikan Ilmu Sosial, 25(1), 24-40.

Silva, C., Jover, C., Da Fonseca, D., Esteves, F., \& Deruelle, C. (2019). Acting on observed social exclusion and pro-social behaviour in autism spectrum disorder. Autism, 24(1), 233-245. https://doi.org/10.1177/1362361319857578

Smith, P. B. (2015). To Lend Helping Hands: In-Group Favoritism, Uncertainty Avoidance, and the National Frequency of Pro-Social Behaviors. Journal of Cross-Cultural Psychology, 46(6), 759771. https://doi.org/10.1177/0022022115585141

Sugiyono. (2009). Metode Penelitian Kuantitatif, Kualitatif dan $R \& D$. Bandung: Alfabeta.

Suyatno, Pambudi, D. I., Mardati, A., Wantini, Eka, \& Yoyo. (2019). The Education Values of Indonesian Teachers: Origin, Importance, and Its Impact on Their Teaching Suyatno. International Journal of Instruction, 12(3), 633-650. https://doi.org/10.29333/iji.2019.12338a

Toumbourou, J. W. (2016). Beneficial Action within Altruistic and Prosocial Behavior. Review of General Psychology, 20(3), 245-258. https://doi.org/10.1037/gpr0000081

Ulber Silalahi. (2009). Metode Penelitian Sosial. Bandung: PT.Refika Aditama.

Widodo, H. (2018). Pengembangan Respect Education Melalui Pendidikan Humanis Religius Di Sekolah. Lentera Pendidikan: Jurnal Ilmu Tarbiyah dan Keguruan.

https://doi.org/10.24252/lp.2018v21n1i10 